\title{
Antioxidant effects of tea catechins on the shelf life of raw minced duck meat
}

\author{
Lili TIAN ${ }^{1,2,3}$, Jian'an HUANG $^{1,2 *}$
}

\begin{abstract}
The antioxidant effects of tea catechins (TC) on the shelf life of raw minced duck meat were investigated by measuring the levels of lipid peroxidation, globulin precipitation, and TC residues during refrigeration $\left(4^{\circ} \mathrm{C}\right)$. TC was added to the raw minced duck meat at 0 (T0), 300 (T300), 500 (T500), 800 (T800), or 1000 (T1000) $\mathrm{mg} / \mathrm{kg}$. Treated samples were stored in a refrigerated $\left(4^{\circ} \mathrm{C}\right)$ display cabinet under aerobic conditions for $10 \mathrm{~d}$. The levels of lipid peroxidation (thiobarbituric acid reactive substances), globulin precipitation, and TC residues were measured every $2 \mathrm{~d}$. TC-treated duck meat displayed significantly lower $(P<0.05)$ lipid peroxidation compared with the control under refrigerated aerobic conditions, indicating that the TCs have antioxidant activity. As the TC concentration increased, globulin precipitation decreased under aerobic conditions. At the same time, the level of TC residues first increased and then decreased. These results showed that addition of TC improved the lipid stability, decreased globulin precipitation, and decreased the level of TC residues in minced duck meat. Therefore, TCs are a promising additive for inhibiting the oxidation of duck meat, and could be used to maintain food product quality.
\end{abstract}

Keywords: duck meat shelf life; tea catechins (TC); malondialdehyde (MDA); protein content; catechin deposition.

Practical Application: Tea catechins additives for extending the shelf life of raw minced meat.

\section{Introduction}

Duck meat is enjoyed by people throughout the world because of its distinct taste, and is especially popular in Asia. Nutritional analysis has revealed that duck meat is rich in digestible proteins, polyunsaturated fatty acids, vitamins, and inorganic elements (Adeola, 2006; Liu et al., 2013). Peking Duck and Nanjing Duck are marinated duck dishes that have been famous for hundreds of years (Liu et al., 2013). People in Nanjing reportedly consume about 100 million ducks every year, and the sale of Peking Duck in China is estimated to generate 110 billion in revenue every year. Fresh duck meat products are commonly refrigerated $\left(25^{\circ} \mathrm{C}\right)$ to increase their shelf life (Radha Krishnan et al., 2014).

Duck feed is supplemented with a number of additives. However, the abuse of additives has resulted in safety issues with consumption of duck meat. Tea, which is rich in catechins, is a good source of antioxidants. Tea catechins (TCs) have good antioxidant activity and are nontoxic in multiple food models (Bao et al., 2009). Typical tea catechins are epicatechin (EC), epigallocatechin (EGC), epicatechin gallate (ECG), epigallocatechin gallate (EGCG), $( \pm$ )-catechin (DL-C), and gallocatechin gallate (GCG) (Quelhas et al., 2010; Weisburger et al., 2002). Many studies have investigated the use of green tea extract as an additive in various foods, including oil, pork sausages, pig liver pâté, and oysters (Siripatrawan \& Noipha, 2012; Pateiro et al., 2014). However, only a few studies, such as that by Tang et. al. (2001), have investigated the effect of TCs on the shelf life of duck meat using oxidation profiling. To date, no studies have evaluated the effect of TC residues on the shelf life of fresh meat under refrigerated aerobic conditions.

Compared with gas chromatography and high-performance liquid chromatography (HPLC) methods, nuclear magnetic resonance (NMR) spectroscopy is a rapid technique that is not prone to sample loss, and allows for identification and quantification of compounds (Surai et al., 2000; Liu et al., 2007). Therefore, NMR spectroscopy is a superb tool for meat characterization (Sacco et al., 2005; Shintu et al., 2007).

The aim of this study was to determine the effectiveness of TCs for improving the shelf life of raw duck meat. This was evaluated by measuring thiobarbituric acid reactive substances (TBARS) as a marker of lipid peroxidation, determining the levels of TC residues, and evaluating globulin precipitation using a HPLC kit. Oxidation of raw duck meat during refrigerated storage was evaluated using NMR.

\section{Materials and methods}

\subsection{Chemicals}

All chemicals were purchased from Changsha Chemical Company and Sigma Chemical Co., Ltd. A green tea extract containing TCs (70\% purity) was obtained from Kinglong Natural Plant Products Industry Ltd. (Changsha, China). HPLC analysis showed the extract contained $40.289 \%$ EGCG, $10.976 \%$ 
EGC, 9.206\% ECG, 5.160\% EC, 1.904\% DL-C, and 2.462\% GCG. The remaining $14 \%$ was $( \pm)$-catechins and caffeine.

\subsection{Sample preparation}

Duck breast meat was purchased from a local market and trimmed to remove the bones, skin, and surface fat. The meat was then minced and treated with TC at 0 (T0), 300 (T300), 500 (T500), 800 (T800), or 1000 (T1000) mg/kg. To ensure distribution of the TC throughout the sample, the TC were mixed with $50 \mathrm{~mL}$ of distilled water and dispersed as a fine aerosol over the minced samples. The samples were then mixed thoroughly using a household blender. To prepare control samples, distilled water was added instead of the TCs. The samples were cut into pieces $\left(5 \mathrm{~cm}^{3}\right)$, minced using a $4-\mathrm{mm}$ plate, and then formed into patties (30 g) using a conventional burger maker. The samples were covered and placed in a refrigerated display cabinet $\left(4^{\circ} \mathrm{C}\right)$ under a fluorescent light (616 lx) for $10 \mathrm{~d}$ (Tang et al., 2006). Fifteen ducks were used for each replication. TBARS, protein content, and TC residues were measured on days $0,1,3,5,7$, and 10 . The oxidation of raw duck meat was evaluated using NMR analysis on day 10 .

\subsection{Determination of globulin precipitation}

Each sample was mixed with $10 \%$ saline in a 1:9 ratio of tissue: saline. The supernatant was assayed using a kit and an established method. The absorbance at $540 \mathrm{~nm}$ was measured for each sample in a cuvette with a $1 \mathrm{~cm}$ light path. The absorbance for the blank was zero.

\subsection{Lipid peroxidation measurements}

Lipid stability was measured and indicated as the TBARS level. TBARS index was measured by using the commercially suggested TBA method (Nanjing Jiancheng Bioengineering Institute, Nanjing, China), which is based on the principles in the previous report (Buege \& Aust, 1978). Briefly, which was based upon the spectrophotometric measurement by color produced during the reaction time of TBA with MDA. MDA concentrations were computed by the suction rate of TBARS at $532 \mathrm{~nm}$ (Mao et al., 2012).

\subsection{Determination of catechin residues}

Catechin residues were extracted by mixing $5 \mathrm{~g}$ of duck breast meat with $12 \mathrm{~mL}$ of alcohol at $45^{\circ} \mathrm{C}$ for $25 \mathrm{~min}$. The sample was filtered, and the filtrate was retained. The residue was extracted with another $8 \mathrm{~mL}$ of alcohol at $45^{\circ} \mathrm{C}$ for $20 \mathrm{~min}$. After filtering, the filtrate was combined with that from the first extraction, and the volume was adjusted to $25 \mathrm{~mL}$ with alcohol (Suganuma et al., 1998). The filtrate was then filtered through a $0.45-\mu \mathrm{m}$ filter (Millipore, Billerica, MA) before analysis by HPLC (LC-10ATVP, Shimadzu, Tokyo, Japan) (Xiong et al., 2013). The injection volume was $10 \mu \mathrm{L}$. The HPLC was equipped with a C18 column $(200 \times 4.6$ i.d., $5 \mu \mathrm{m}$, Welchorm). The mobile phase was a mixture of pure water (A) and $N, N$-dimethylformamide/ methanol/acetic acid $(40 / 2 / 1.5, \mathrm{v} / \mathrm{v} / \mathrm{v} ; \mathrm{B})$. The samples were eluted at $35^{\circ} \mathrm{C}$ with a mobile phase flow rate of $1 \mathrm{~mL} / \mathrm{min}$. Monitoring was performed at $278 \mathrm{~nm}$. The retention times were compared with those of authentic standards, and peaks were identified for further study.

\subsection{Preliminary analysis of the properties of the oxidized compounds}

The oxidized compounds were evaluated for the following physical properties: color, taste, moisture absorbance, solubility in water, and solubility in organic solvents (ethanol, propylene glycol, glycerin). The oxidized compounds were also analyzed by ultraviolet-visible spectroscopy.

\subsection{Oxide preparation and characterization}

A photodiode array detector (SPD-M20A), system controller (SCL-10ATVP), pump (LC-10ATVP), and LC-solution data system all from Shimadzu were used to obtain photodiode array spectra from 200-600 nm. A Hypersil C18 column (150 mm $\times 4.6 \mathrm{~mm}$ i.d., $5 \mu \mathrm{m}$, Shimadzu) was used for oxide analysis using an established method (Wang et al., 2004). The mobile phase was a mixture of $2 \%$ acetic acid in distilled water (A) and methanol (B). The elution was performed with an $A: B$ ratio of $13: 7(\mathrm{v} / \mathrm{v})$ and a flow rate of $30.0 \mathrm{~mL} / \mathrm{min}$. The injection volume was $100 \mu \mathrm{L}(50 \mathrm{mg} / \mathrm{mL})$. The sample was injected into the preparative HPLC system and analyzed on a phase with a separation time of $4 \mathrm{~min}$ (Figure 1).

Liquid chromatography-mass spectrometry was performed using an Agilent 1100 LC/MSD SL (Agilent Technologies, USA) with an atmospheric pressure chemical ionization interface (Sang et al., 2004) and a Zorbax C8 column $(200 \mathrm{~mm} \times 4.6 \mathrm{~mm}$ i.d., Agilent Technologies). The flow rate was $0.9 \mathrm{~mL} / \mathrm{min}$. The eluents were mixed $(75: 25, \mathrm{v} / \mathrm{v})$ with methanol and water containing $4 \mathrm{~g} / \mathrm{L}$ ammonium. The effluent from the $\mathrm{LC}$ column was passed through the ion source $\left(150^{\circ} \mathrm{C}\right)$ and a heated nebulizer probe $\left(400{ }^{\circ} \mathrm{C}\right)$ with nitrogen as the drying gas $\left(5 \mathrm{~L} / \mathrm{min}, 350{ }^{\circ} \mathrm{C}\right)$. The nebulizer pressure was set to 60 psi. Full scan mode and spectra were acquired from $\mathrm{m} / z 50$ to 1000 . A Varian Unity INOVA $300 \mathrm{NMR}$ was used to obtain NMR spectra. The chemical shifts $(\delta)$ are reported in ppm relative to the residual solvent signals at $\delta \mathrm{H} 3.35$, and the coupling constants $(J)$ are in $\mathrm{Hz}$ (Wang et al., 2004).

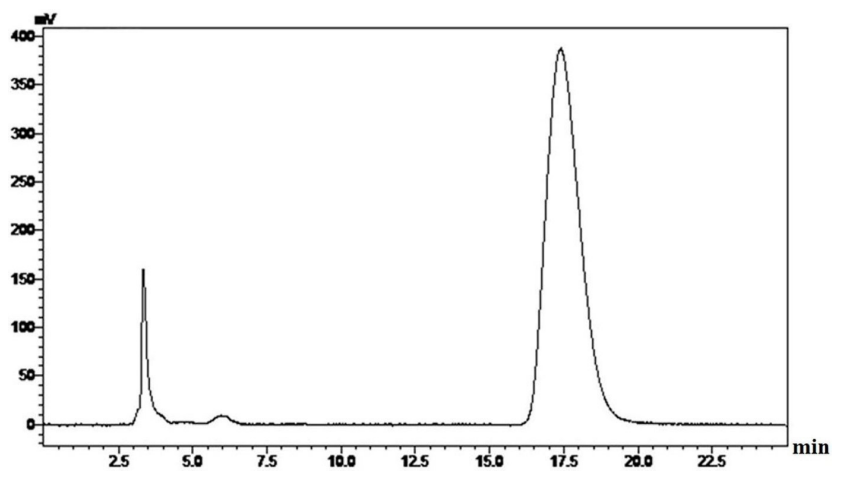

Figure 1. Chromatogram from preparative high performance liquid chromatography of the oxidized compounds. 


\subsection{Statistical analyses}

Data are reported as mean values $(n=3)$ with standard errors of the means. SPSS software was used for data analysis (Version 20.0; SPSS, Chicago, IL). One-way analysis of variance, Duncan's multiple range tests, descriptive statistics (mean and standard deviation), and linear regression analysis were applied for statistical analysis. $P$ values of less than 0.05 were considered statistically significant.

\section{Results and discussion}

\subsection{Lipid stability of duck breast meat}

Lipid peroxidation, a free radical chain reaction, greatly reduces the shelf life of meat products, and oxidative stability is critical for food storage. Measurement of TBARS is the most widely used method to determine the extent of lipid peroxidation (Namal Senanayake, 2013). In this study, the samples were not significantly different $(P>0.05)$ on day 0 (Figure 2 ), which confirmed that the samples were uniform. During storage, the TBARS values of the treated groups increased compared with the control. Interestingly, the TBARS values of duck breast treated with T500, T800, and T1000 mg/kg were much lower than that of the control $(P<0.05)$. The TBARS values of duck breast treated with T500 works best in all deals before day7. The effect decreased after 7 days. These results indicated that the addition of TC to the duck breast meat could significantly inhibit lipid peroxidation of the meat. This is consistent with a previous report (Korczak et al., 2007) of TC from green tea largely inhibiting lipid peroxidation in frozen minced pork. However, the inhibitory effect of the TCs depended on the concentration, and a low TC concentration (T300 mg/kg) did not inhibit the lipid peroxidation, with no change in the TBARS value.

TCs are excellent electron donors and can scavenge reactive oxygen species in vitro. In addition, TC antioxidant activity is correlated with the phenolic content (Anandh Babu \& Liu, 2008; Osman, 2011; Nakagawa \& Yokozawa, 2002; Liang et al., 2011; Mei et al., 2013; Guo et al., 1999). The antioxidant activity is largely dependent on chelating free redox-active transition metal ions, which can initiate free radical oxidation chain reactions (Nanjo et al., 1993; Qin et al., 2013; Georgantelis et al., 2007; Michalak, 2006).

However, these results were not consistent with the results of a previous report (Tang et al., 2006), where no significant differences were found among the TBARS values in minced beef patties with different concentrations under both aerobic and MAP conditions. This could be explained by different packing conditions and different meat types, which might affect the antioxidant activity of the TCs.

\subsection{Globulin precipitation in the duck meat patties during storage}

As natural polyphenols, TCs are capable of inhibiting amyloid formation and destabilizing preformed amyloid fibrils, which are cytotoxic because they bind with and disrupt cellular membranes (Murphy, 2007; Kagan et al., 2002; Huang et al., 2009). Furthermore, amyloid fibrillation of lysozyme enhanced the binding of TCs to proteins to form amorphous aggregates (Richard et al., 2006; Siebert et al., 1996; He et al., 2009). In the present study, the level of globulin precipitation in both the control and treatment groups increased, decreased, and then increased again after day 5 (Figure 3 ). After storage for $1 \mathrm{~d}$, the protein content of the control sample was significantly $(P<0.05)$ higher than the protein content of the TC treated sample. Interestingly, on the fifth day, all the samples treated with TCs at different concentrations exhibited significantly $(P<0.05)$ lower globulin precipitation than the control. These results show that the addition of TC to the duck meat did not improve globulin precipitation for short-term storage $(5 \mathrm{~d})$, but high precipitated globulin contents were observed for TC800 and TC1000 after storage for 7-10 d. In an earlier study, the protease activity was closely correlated with a series of biochemical changes in duck meat during storage (Dai et al., 2001). As the storage time increased, protein in the duck muscle degraded because of endogenous protease autolysis, and eventually, the muscle fibers were lost because of organization characteristics. The globulin precipitation induced by TCs is reversible, and involves inhibition of protease (Zhang, 1996). Together with the antioxidant activity, these results suggest TCs could protect against cytotoxicity induced by amyloid assemblies.

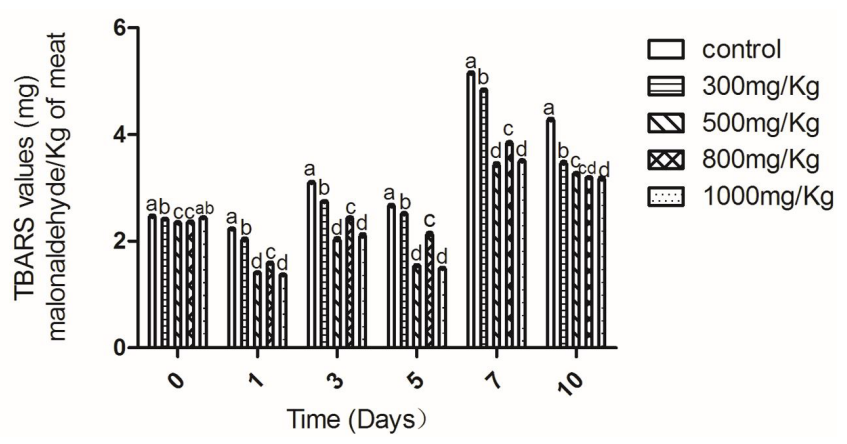

Figure 2. Changes in the TBARS values of duck breast meat during refrigerated storage. Letters a, b, c, and d indicate significant differences $(p<0.05)$ between the control and experimental group.

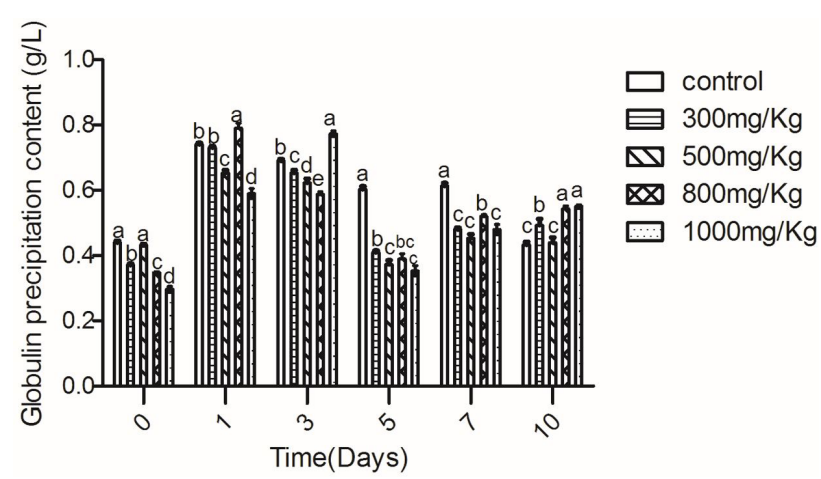

Figure 3. Changes in the content of precipitated globulin in duck breast meat during refrigerated storage. Letters a, b, c, and d indicate significant differences $(\mathrm{p}<0.05)$ between the control and experimental group. 


\subsection{Catechin residues}

Proper incorporation of the TCs into duck meat is important to ensure its antioxidant effect (Namal Senanayake, 2013). The use of TC as an additive in duck breast meat results in the presence of TC residues in the meat. For TC additive levels of $300,500,800$, and $1000 \mathrm{mg} / \mathrm{kg}$, the level of TC residues in the meat increased from day 0 to day 3 , and then decreased from day 3 to day 10 (Figure 4). For TC additive levels of $300,500,800$, and $1000 \mathrm{mg} / \mathrm{kg}$, the levels of TCs residues on days 3,5 , and 7 were significantly different $(P<0.05)$ among the sample groups, whereas the differences on the other days were not statistically significant. The sedimentation of catechins is proportional to the amount of addition.

As a result of oxidation, the addition of TC to duck breast meat results in retention of CAF, EGC, and ECG, and loss of GCG, DL- C, EC, and EGCG. Based on the EGCG oxidation results, the ester-type catechins showed the highest degree of oxidation. This is consistent with the TCs containing a gallic ester bond having higher fibril-deposition than other TCs. This is likely because the ester-type catechins have stronger the antioxidant ability than other catechins because of the types of transformations they can undergo.

\subsection{Oxidation analysis of duck breast meat using NMR}

Separation of the oxidized compounds

To understand the potential mechanism of antioxidant and anticytotoxic activity, the contents of oxidized compounds in TC-treated duck meat were determined. Separation of $30 \mathrm{mg}$ of the sample through preparative HPLC revealed that one peak was resolved in about 4 min (Figure 1). Pure compounds were obtained after recrystallization of these fractions with aqueous methanol, which removed minor impurities.

\section{Preliminary analysis of the oxidized compounds}

The oxidized compounds were light brown powders with a bitter taste that absorbed moisture and were soluble in water and organic solvents (e.g. ethanol, propylene glycol, and glycerin). Two absorption peaks were detected at 210 and $265 \mathrm{~nm}$ in the ultraviolet-visible spectrum. For the peak at $210 \mathrm{~nm}$, a red shift was induced with an increase in the sample concentration. By contrast, the peak at $265 \mathrm{~nm}$ was relatively stable. From the mass spectrometry data (Figure 5), a molecular weight of 212 was calculated for the oxidized compounds.

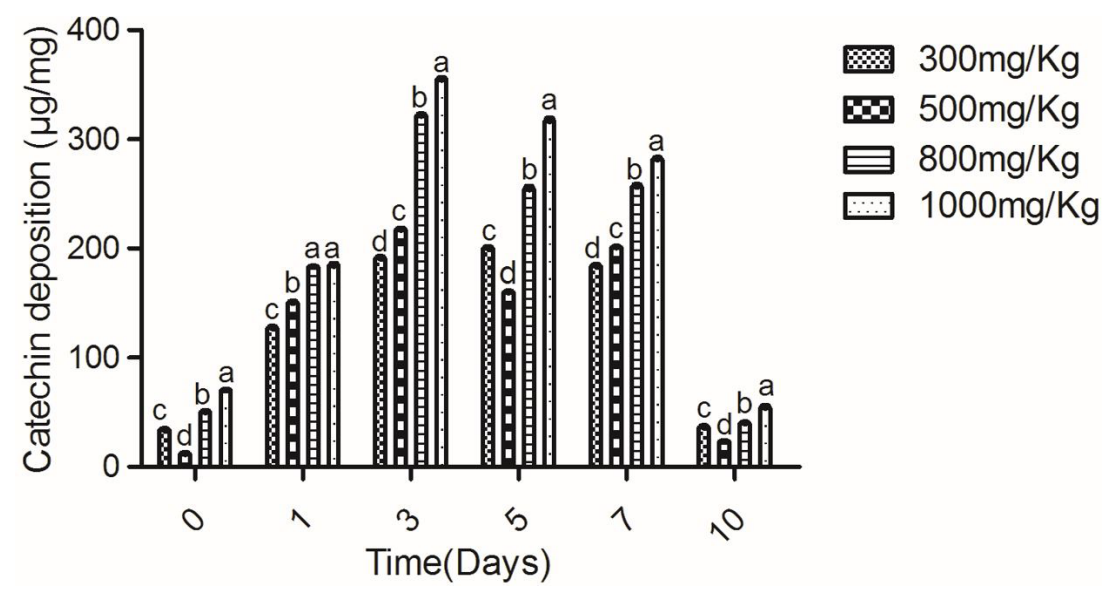

Figure 4. Changes in the content of TC residues in duck breast meat during refrigerated storage. Letters a, b, c, and d indicate significant differences $(\mathrm{p}<0.05)$ between the experimental group.

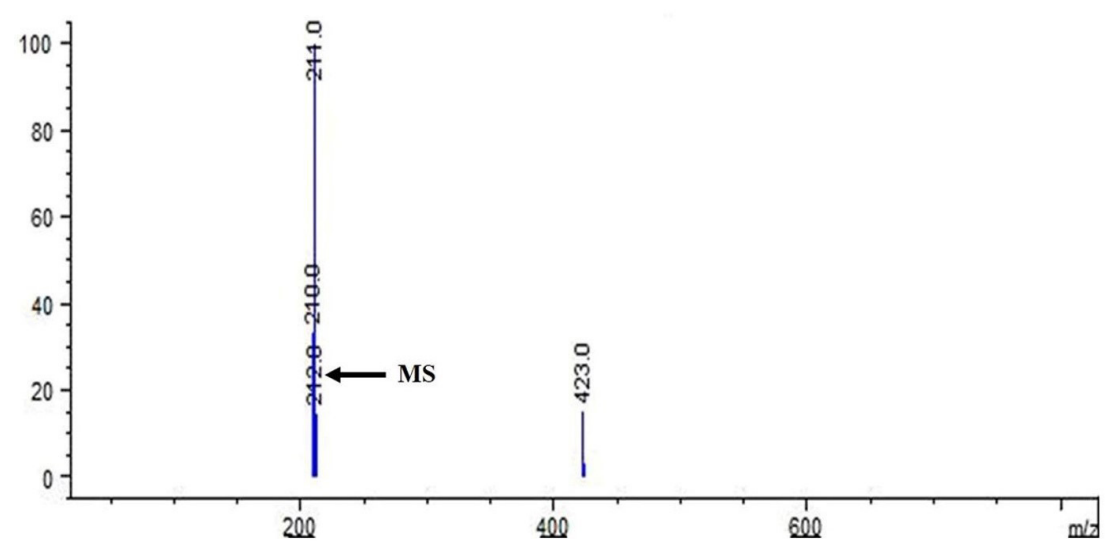

Figure 5. Mass spectrum of the oxidized compounds. 


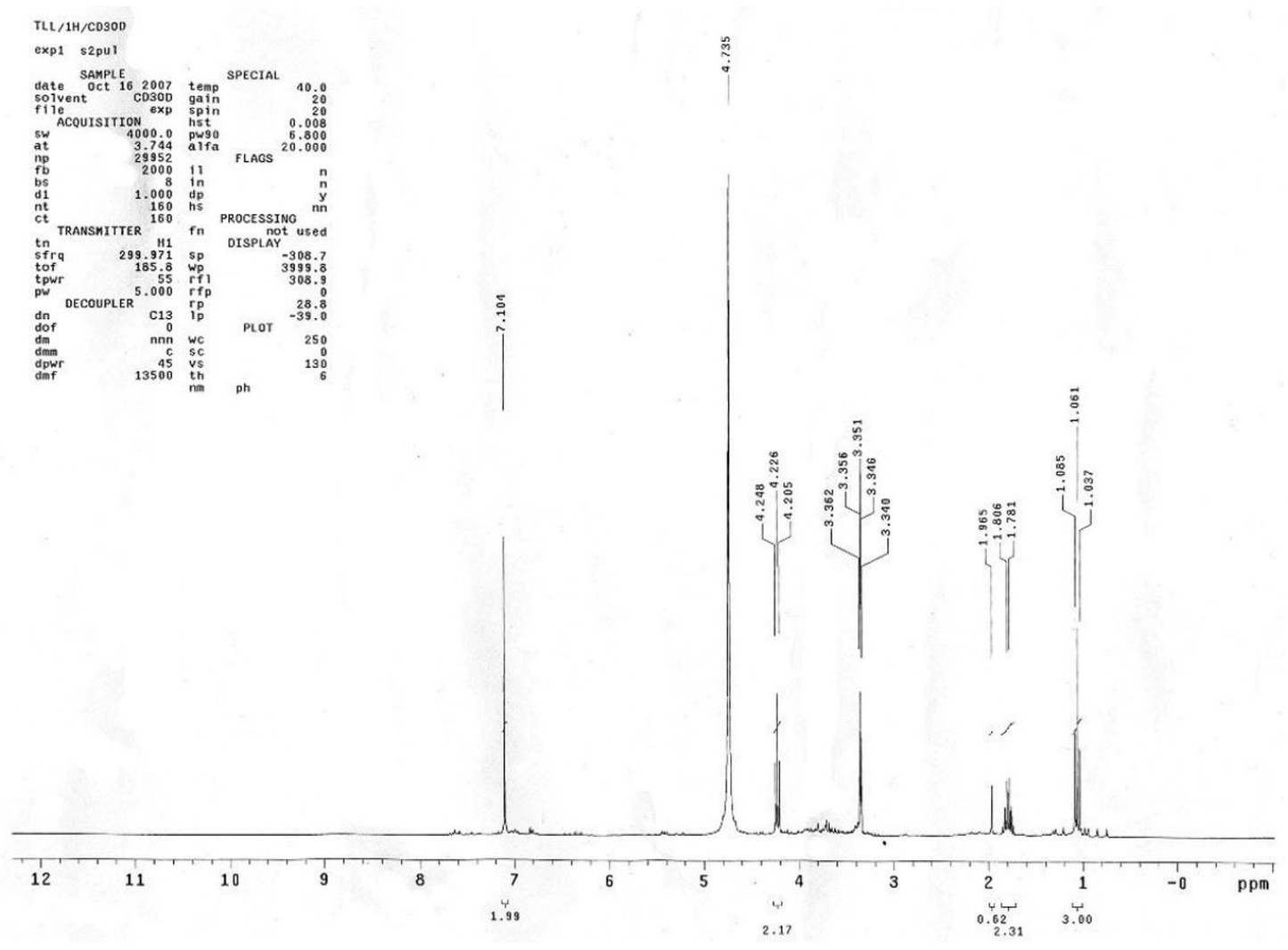

Figure 6. ${ }^{1} \mathrm{H}-\mathrm{NMR}$ of the oxidized compound.

${ }^{1} \mathrm{H}-\mathrm{NMR}$ spectroscopy (Figure 6) was used to identify the oxidized compounds. Interestingly, the oxidized compounds possessed a benzene ring with nine hydrogen atoms. The peak for the solvent (methanol) obscured the hydroxyl peak (data not shown) in line with Jiang et al. (2011). From these results, we speculated that the oxidized compounds were transformed into propyl gallate $(\mathrm{PG})$. However, further research is required to clarify this.

Among the gallic acid derivatives, $\mathrm{PG}$ is widespread in plants. Catechins with a gallic ester bond are more efficient than other catechins at converting lysozyme fibrils to amorphous aggregates (He et al., 2009). The antioxidant mechanism of PG is based on its capacity to sequester metal ions, which can catalyze the formation of OH by the Haber-Weiss reaction (Shahidi et al., 1992). PG aggregates platelets and dilates blood vessels, and is promising drug for the treatment of cardiovascular diseases. In addition, PG, is widely-used as an antioxidant in medicines and food, and has been approved by the Food and Drug Administration and World Health Organization (Wu \& Yang, 1993). Propyl gallate (PG), widely used as an antioxidant in foods, is carcinogenic to mice and rats (Kobayashi et al., 2004). TCs are a natural antioxidant that could be used an alternative to PG for food preservation. They can oxidize the crude product of gallic acid ester and convert cytotoxic fibrils into amorphous aggregates. PG has been investigated as a potential chemopreventive agent in several animal experiments (King \& McCay, 1983; Hirose et al., 1988, 1993). Thus, PG is recognized as being the important synthetic antioxidant.

\section{Conclusion}

NMR analysis of the lipid fraction and the protein level revealed that TCs reduce protein oxidation and inhibit lipid peroxidation in duck breast meat stored at $4{ }^{\circ} \mathrm{C}$. TC-treated duck breast meat is acceptable after up to $10 \mathrm{~d}$ of refrigerated storage. The T500 of TC is the optimal concentration for duck breast meat.TC can be used to extend the shelf life of poultry meat under refrigeration $\left(4^{\circ} \mathrm{C}\right)$, and could be used as a partial substitute for chemical preservatives in food.

\section{Acknowledgements}

This study was supported by the Science and Technology Foundation of Hunan Province (Grant No. 2007FJ1006) and the Hunan Provincial Key Laboratory for Germplasm Innovation and Utilization of Crop Open topic (Grant No. 16KFXM10).

\section{References}

Adeola, O. (2006). Review of research in duck nutrient utilization. International Journal of Poultry Science, 5(3), 201-218. http://dx.doi. org/10.3923/ijps.2006.201.218.

Anandh Babu, P., \& Liu, D. (2008). Green tea catechins and cardiovascular health: an update. Current Medicinal Chemistry, 15(18), 1840-1850. http://dx.doi.org/10.2174/092986708785132979. PMid:18691042.

Bao, S., Xu, S. Y., \& Wang, Z. (2009). Antioxidant activity and properties of gelatin films incorporated with tea polyphenol-loaded chitosan nanoparticles. Journal of the Science of Food and Agriculture, 89(15), 2692-2700. http://dx.doi.org/10.1002/jsfa.3775. 
Buege, J. A., \& Aust, S. D. (1978). Microsomal lipid peroxidation. Methods in Enzymology, 52, 302-310. http://dx.doi.org/10.1016/ S0076-6879(78)52032-6. PMid:672633.

Dai, J., Wang, H. X., Chen, S. W., \& Tang, J. (2001). Study on the analytical methods of catechins in tea and green tea polyphenol samples by high performance liquid chromatography. Se Pu, 19(5), 398-402. PMid:12545432.

Georgantelis, D., Ambrosiadis, I., Katikou, P., Blekas, G., \& Georgakis, S. A. (2007). Effect of rosemary extract, chitosan and $\alpha$-tocopherol on microbiological parameters and lipid oxidation of fresh pork sausages stored at $4{ }^{\circ} \mathrm{C}$. Meat Science, 76(1), 172-181. http://dx.doi. org/10.1016/j.meatsci.2006.10.026. PMid:22064204.

Guo, Q., Zhao, B., Shen, S., Hou, J., Hu, J., \& Xin, W. (1999). ESR study on the structure-antioxidant activity relationship of tea catechins and their epimers. Biochimica et Biophysica Acta, 1427(1), 13-23. http://dx.doi.org/10.1016/S0304-4165(98)00168-8. PMid:10082983.

He, J., Xing, Y. F., Huang, B., Zhang, Y. Z., \& Zeng, C. M. (2009). Tea catechins induce the conversion of preformed lysozyme amyloid fibrils to amorphous aggregates. Journal of Agricultural and Food Chemistry, 57(23), 11391-11396. http://dx.doi.org/10.1021/jf902664f. PMid:19904937.

Hirose, M., Masuda, A., Fukushima, S., \& Ito, N. (1988). Effects of subsequent antioxidant treatment on 7,12-dimethylbenz[a] anthracene-initiated carcinogenesis of the mammary gland, ear duct and forestomach in Sprague-Dawley rats. Carcinogenesis, 9(1), 101-104. http://dx.doi.org/10.1093/carcin/9.1.101. PMid:3121204.

Hirose, M., Yada, H., Hakoi, K., Takahashi, S., \& Ito, N. (1993). Modification of carcinogenesis by alpha-tocopherol, tbutylhydroquinone, propyl gallate and butylated hydroxytoluene in a rat multi-organ carcinogenesis model. Carcinogenesis, 14(11), 2359-2364. http:// dx.doi.org/10.1093/carcin/14.11.2359. PMid:8242867.

Huang, B., He, J., Ren, J., Yan, X. Y., \& Zeng, C. M. (2009). Cellular membrane disruption by amyloid fibrils involved intermolecular disulfide cross-linking. Biochemistry, 48(25), 5794-5800. http:// dx.doi.org/10.1021/bi900219c. PMid:19449893.

Jiang, H. Y., Shii, T., Matsuo, Y., Tanaka, T., Jiang, Z. H., \& Kouno, I. (2011). A new cate- chin oxidation product and polymeric polyphenols of post-fermented tea. Food Chemistry, 129(3), 830-836. http://dx.doi. org/10.1016/j.foodchem.2011.05.031. PMid:25212306.

Kagan, B. L., Hirakura, Y., Azimov, R., Azimova, R., \& Lin, M. C. (2002). The channel hypothesis of alzheimer's disease: current status. Peptides, 23(7), 1311-1315. http://dx.doi.org/10.1016/S01969781(02)00067-0. PMid:12128087.

King, M. M., \& McCay, P. B. (1983). Modulation of tumor incidence and possible mechanisms of inhibition of mammary carcinogenesis by dietary antioxidants. Cancer Research, 43(5, Suppl), 2485-2490. PMid:6403238.

Kobayashi, H., Oikawa, S., Hirakawa, K., \& Kawanishi, S. (2004). Metalmediated oxidative damage to cellular and isolated DNA by gallic acid, a metabolite of antioxid ant propyl gallate. Mutation Research, 558(1-2), 111-120. http://dx.doi.org/10.1016/j.mrgentox.2003.11.002. PMid:15036124.

Korczak, D. J., Connolly, B., Baron, T., Katzman, D. K., \& Bernstein, S. (2007). Experience with image-guided gastrostomy and gastrojejunostomy tubes in children and adolescents with primary psychiatric illness. International Journal of Eating Disorders, 40(7), 645-651. http://dx.doi.org/10.1002/eat.20404. PMid:17584868.

Liang, J., Li, F., Fang, Y., Yang, W., An, X., Zhao, L., Xin, Z., Cao, L., \& $\mathrm{Hu}, \mathrm{Q}$. (2011). Synthesis, characterization and cytotoxicity studies of chitosan-coated tea polyphenols nanoparticles. Colloids and
Surfaces. B, Biointerfaces, 82(2), 297-301. http://dx.doi.org/10.1016/j. colsurfb.2010.08.045. PMid:20888740.

Liu, C., Pan, D., Ye, Y., \& Cao, J. (2013). ${ }^{1}$ H NMR and multivariate data analysis of the relationship between the age and quality of duck meat. Food Chemistry, 141(2), 1281-1286. http://dx.doi.org/10.1016/j. foodchem.2013.03.102. PMid:23790914.

Liu, Y., Xu, X. L., \& Zhou, G. H. (2007). Changes in taste compounds of duck during processing. Food Chemistry, 102(1), 22-26. http:// dx.doi.org/10.1016/j.foodchem.2006.03.034.

Mao, G. X., Zheng, L. D., Cao, Y. B., Chen, Z. M., Lv, Y. D., Wang, Y. Z., Hu, X. L., Wang, G. F., \& Yan, J. (2012). Antiaging effect of pine pollen in human diploid fibroblasts and in a mouse model induced by d-galactose. Oxidative Medicine and Cellular Longevity, 2012, 750963. http://dx.doi.org/10.1155/2012/750963. PMid:22577492.

Mei, J., Yuan, Y., Wu, Y., \& Li, Y. J. (2013). Characterization of edible starch-chitosan film and its application in the storage of mongolian cheese. International Journal of Biological Macromolecules, 57, 17-21. http://dx.doi.org/10.1016/j.ijbiomac.2013.03.003. PMid:23500443.

Michalak, A. (2006). Phenolic compounds and their antioxidant activity in plants growing under heavy metal stress. Polish Journal of Environmental Studies, 15, 523-530.

Murphy, R. M. (2007). Kinetics of amyloid formation and membrane interaction with amyloidogenic proteins. Biochimica et Biophysica Acta, 1768(8), 1923-1934. http://dx.doi.org/10.1016/j.bbamem.2006.12.014. PMid:17292851.

Nakagawa, T., \& Yokozawa, T. (2002). Direct scavenging of nitric oxide and superoxide by green tea. Food and Chemical Toxicology, 40(12), 1745-1750. http://dx.doi.org/10.1016/S0278-6915(02)00169-2. PMid:12419687.

Namal Senanayake, S. P. (2013). Green tea extract: chemistry, antioxidant properties and food applications: a review. Journal of Functional Foods, 5(4), 1529-1541. http://dx.doi.org/10.1016/j.jff.2013.08.011.

Nanjo, F., Honda, M., Okushio, K., Matsumoto, N., Ishigaki, F., Ishigami, T., \& Hara, Y. (1993). Effects of dietary tea catechins on alpha-tocopherol levels, lipid peroxidation, and erythrocyte deformability in rats fed on high palm oil and perilla oil diets. Biological \& Pharmaceutical Bulletin, 16(11), 1156-1159. http://dx.doi.org/10.1248/bpb.16.1156. PMid:8312875.

Osman, A. M. (2011). Multiple pathways of the reaction of 2,2-diphenyl1-picry lhydrazyl radical (DPPH.) with (+)-catechin: evidence for the formation of a covalent adduct between DPPH. and the oxidized form of the polyphenol. Biochemical and Biophysical Research Communications, 412(3), 473-478. http://dx.doi.org/10.1016/j. bbrc.2011.07.123. PMid:21835163.

Pateiro, M., Lorenzo, J. M., Amado, I. R., \& Franco, D. (2014). Effect of addition of green tea, chestnut and grape extract on the shelflife of pig liver pâté. Food Chemistry, 147, 386-394. http://dx.doi. org/10.1016/j.foodchem.2013.09.153. PMid:24206734.

Qin, Y. Y., Yang, J. Y., Lu, H. B., Wang, S. S., Yang, J., Yang, X. C., Chai, M., Li, L., \& Cao, J. X. (2013). Effect of chitosan film incorporated with tea polyphenol on quality and shelf life of pork meat patties. International Journal of Biological Macromolecules, 61, 312-316. http://dx.doi.org/10.1016/j.ijbiomac.2013.07.018. PMid:23916647.

Quelhas, I., Petisca, C., Viegas, O., Melo, A., Pinho, O., \& Ferreira, I. M. P. L. V. O. I. (2010). Effect of green tea marinades on the formation of heterocyclic aromatic amines and sensory quality of pan-fried beef. Food Chemistry, 122(1), 98-104. http://dx.doi.org/10.1016/j. foodchem.2010.02.022.

Radha Krishnan, K., Babuskin, S., Azhagu Saravana Babu, P., Sasikala, M., Sabina, K., Archana, G., Sivarajan, M., \& Sukumar, M. (2014). 
Antimicrobial and antioxidant effects of spice extracts on the shelf life extension of raw chicken meat. International Journal of Food Microbiology, 171, 32-40. http://dx.doi.org/10.1016/j. ijfoodmicro.2013.11.011. PMid:24308943.

Richard, T., Lefeuvre, D., Descendit, A., Quideau, S., \& Monti, J. P. (2006). Recognition characters in peptide-polyphenol complex formation. Biochimica et Biophysica Acta, 1760(6), 951-958. http:// dx.doi.org/10.1016/j.bbagen.2006.01.005. PMid:16527409.

Sacco, D., Brescia, M. A., Buccolieri, A., \& Caputi Jambrenghi, A. (2005). Geographical origin and breed discrimination of Apulian lamb meat samples by means of analytical and spectroscopic determinations. Meat Science, 71(3), 542-548. http://dx.doi. org/10.1016/j.meatsci.2005.04.038. PMid:22060931.

Sang, S., Lambert, J. D., Tian, S., Hong, J., Hou, Z., Ryu, J. H., Stark, R. E., Rosen, R. T., Huang, M. T., Yang, C. S., \& Ho, C. T. (2004). Enzymatic synthesis of tea theaflavin derivatives and their anti-inflammatory and cytotoxic activities. Bioorganic \& Medicinal Chemistry, 12(2), 459-467. http://dx.doi.org/10.1016/j.bmc.2003.10.024. PMid:14723964.

Shahidi, F., Janitha, P. K., \& Wanasundara, P. D. (1992). Phenolic antioxidants. Critical Reviews in Food Science and Nutrition, 32(1), 67-103. http://dx.doi.org/10.1080/10408399209527581. PMid:1290586.

Shintu, L., Caldarelli, S., \& Franke, B. M. (2007). Preselection of potential molecular markers for the geographic origin of dried beef by HRMAS NMR spectroscopy. Meat Science, 76(4), 700-707. http://dx.doi. org/10.1016/j.meatsci.2007.02.010. PMid:22061247.

Siebert, K. J., Troukhanova, N. V., \& Lynn, P. Y. (1996). Nature of polyphenol-protein interactions. Journal of Agricultural and Food Chemistry, 44(1), 80-85. http://dx.doi.org/10.1021/jf9502459.

Siripatrawan, N., \& Noipha, S. (2012). Active film from chitosan incorporating green tea extract for shelf life extension of pork sausages. Food Hydrocolloids, 27(1), 102-108. http://dx.doi.org/10.1016/j. foodhyd.2011.08.011.

Suganuma, M., Okabe, S., Oniyama, M., Tada, Y., Ito, H., \& Fujiki, H. (1998). Wide distribution of [3H] (-)-epigallocatechin gallate, a cancer preventive tea polyphenol, in mouse tissue. Carcinogenesis,
19(10), 1771-1776. http://dx.doi.org/10.1093/carcin/19.10.1771. PMid:9806157.

Surai, P. F., Brillard, J. P., Speake, B. K., Blesbois, E., Seigneurin, F., \& Sparks, N. H. C. (2000). Phospholipid fatty acid composition, vitamin $\mathrm{E}$ content and susceptibility to lipid peroxidation of duck spermatozoa. Theriogenology, 53(5), 1025-1039. http://dx.doi. org/10.1016/S0093-691X(00)00249-1. PMid:10798481.

Tang, S., Kerry, J. P., Sheehan, D., \& Buckley, J. D. (2001). A comparative study of tea catechins and $\alpha$-tocopherol as antioxidants in cooked beef and chicken meat. European Food Research and Technology, 213(4-5), 286-289. http://dx.doi.org/10.1007/s002170100311.

Tang, S., Ou, S., Huang, X., Li, W. K., Kerry, J. P., \& Buckley, D. J. (2006). Effects of added tea catechins on color stability and lipid oxidation in minced beef patties held under aerobic and modified atmospheric packaging conditions. Journal of Food Engineering, 77(2), 248-253. http://dx.doi.org/10.1016/j.jfoodeng.2005.06.025.

Wang, J., Huang, X., Cao, J., Wang, G., Zhang, Q., \& Ding, L. (2004). Determination of theaflavins in black tea by high performance liquid chromatography. Se Pu, 22(2), 151-153. http://dx.doi.org/10.3724/ SP.J.1123.2013.10015. PMid:15712875.

Weisburger, J. H., Veliath, E., Larios, E., Pittman, B., Zang, E., \& Hara, Y. (2002). Tea polyphenols inhibit the formation of mutagens during the cooking of meat. Mutation Research, 516(1-2), 19-22. http:// dx.doi.org/10.1016/S1383-5718(01)00351-5. PMid:11943606.

Wu, X., \& Yang, X. S. (1993). Synthesis and application of PG. Journal of Guangdong Medical College, 9(2), 7.

Xiong, L. G., Li, J., Li, Y. H., Yuan, L., Liu, S. Q., Huang, J. A., \& Liu, Z. H. (2013). Dynamic changes in catechin levels and catechin biosynthesis-related gene expression in albino tea plants (Camellia sinensis L.). Plant Physiology and Biochemistry, 71, 132-143. http:// dx.doi.org/10.1016/j.plaphy.2013.06.019. PMid:23911731.

Zhang, Y. (1996). Study on protease activity in rabbit meat. Meat Hygiene, (10), 4-6. 